\title{
SMALL BORDER TRAFFIC AND CROSS-BORDER TOURISM BETWEEN POLAND AND THE KALININGRAD OBLAST OF THE RUSSIAN FEDERATION
}

\author{
Renata Anisiewicz, Tadeusz Palmowski \\ Department of Regional Development Geography, University of Gdańsk, Poland
}

Manuscript received: February 13, 2014

Revised version: March 3, 2014

\begin{abstract}
Anisiewicz R., Palmowski T., 2014. Small border traffic and cross-border tourism between Poland and the Kaliningrad Oblast of the Russian Federation. Quaestiones Geographicae 33(2), Bogucki Wydawnictwo Naukowe, Poznań, pp. 79-85, 4 tables, 4 figs. DOI 10.2478/quageo-2014-0017, ISSN 0137-477X.

ABSTRACT: Polish and Russian cross-border cooperation is governed by lawful agreements. The enlargement of the Schengen Area had a significant impact on Kaliningrad Oblast relations and cross-border cooperation with its neighbours. The introduction of visas between Poland and Russia hindered and restricted local border trade which had for years been the only measure mitigating social and economic problems of the cross-border regions. Nevertheless, border traffic between Poland and Kaliningrad grew steadily, to exceed four million in 2012.
\end{abstract}

Poland and Russia, supported by Germany, applied to the EU for small border traffic to cover the entire territory of the Oblast. According to the European Commission, the proposed solution would be a European exception. The agreement on small border traffic came into force on July 27, 2012, covering the entire area of the Kaliningrad Oblast and selected Polish poviats of Pomerania and Warmia-Mazuria voivodeships. Towards the end of the first quarter of 2013, the number of Poles crossing the border showed a rising tendency, and starting from the second through the third quarter of 2013, the number of Russians coming to Poland grew more dynamically.

The visits of Kaliningrad residents, apart from commercially oriented ones, also include recreation, tourism, medical tourism visits, etc. Kaliningrad citizens looking for leisure, recreation and entertainment come to participate in great sporting and cultural events in Gdańsk, Sopot and Gdynia. The local self governments of poviats covered by small border traffic noted a clear upturn in the economies and trade of their regions.

The development of cross-border cooperation, including small border traffic, has not resulted in attracting a substantial number of Polish tourists to the Kaliningrad Oblast, but it has provided such a possibility. This region is quite expensive for the average Pole. However, as scientists from Kaliningrad projected, with the easing of the visa system and the development of transport and tourist infrastructure the role of tourism shows a growing trend.

KEY WORDS: small border traffic, cross-border cooperation, Kaliningrad Oblast

Tadeusz Palmowski, Department of Regional Development Geography, Institute of Geography, University of Gdańsk, Bażyńskiego 4, 80-952 Gdańsk; e-mail: geotpl@ug.edu.pl

Polish and Russian cross-border cooperation is governed by lawful agreements. The most important are the Treaty on Neighbourly Relations and Cooperation between the Republic of Poland and the Russian Federation of 22 May 1992, the memorandum between the Republic of Poland and the Russian Federation on cooperation of north-eastern Polish voivodeships with the Kaliningrad Oblast of the Russian Federation of 22 May 1992, as well as the agreement between the Government of the Republic of Poland and the Government of the Russian Federation on cross-border cooperation of 2 October 1992. The parties agreed to create favourable conditions 
and support direct relations between the regions and cities of both countries, and in particular the Polish north-eastern voivodeships and the Russian Kaliningrad Oblast. They further declared to make all efforts to solve potential disputes hindering cross-border cooperation and to authorise regional and local authorities to conclude relevant agreements. Government proxies for cross-border cooperation were appointed in the process of developing structures supporting cross-border relations and a proxy working body called the Polish-Russian Council was formed for the cooperation of regions of the Republic of Poland and the Kaliningrad Oblast of the Russian Federation. One of its fundamental functions was to advise territorial self governments and other stakeholders about various problems and suggest solutions to improve the cooperation.

The introduction of the Schengen Area in Europe by 25 countries guaranteed a free flow of people. Individual countries gave up control along internal borders and established the external borders of this zone. The lifting of border control was followed by a unification of visa procedures, including those for issuing visas to nationals of third countries.

Under the process of adapting to the common visa policy, Poland and Lithuania lifted visa duties for nationals of countries covered by this visa-free border traffic in Europe. At the same time, in 2003, Poland and Lithuania introduced a visa duty to nationals from countries which are not part of the EU agreement, including Russia, Ukraine and Belarus. Together with Lithuania, Latvia, Estonia and other countries which joined the European Union in 2004, Poland started implementing the Schengen legal order at the end of 2007. On December 21, 2007 the Schengen zone, the area with no border controls, spread to cover 9 further countries, among them Poland, Lithuania, Latvia and Estonia. The enlargement of the Schengen Area had a strong impact on relations of the Kaliningrad Oblast and its cross-border cooperation with neighbours.

It was assumed that major direct effects of the enlargement could be decreasing border traffic of individuals, especially in the initial period, as well as social and economic difficulties in the cross-border regions. To limit the severity and losses projected as a result of implementing the new rules, national competencies of the EU Border States retained certain options for relief and simplifications.

The citizens of the Kaliningrad Oblast, who up to 1 June 2007 were entitled to a free visa pursuant to an agreement dated 25 June 2006 in Sochi between the European Union and the Russian Federation, were to pay 35 euros for a visa. The same fee remained binding for Poles and Lithuanians applying for Russian visas.

In consequence of introducing fees, the number of visas issued in June 2007 by the Polish Consulate in Kaliningrad fell to one-third of the previous month's figure. The falling interest of Kaliningrad inhabitants in travelling to Poland had a clear impact on local travel bureaus, which noted a dropping interest in several-day-long trips to Gdańsk by up to $80 \%$. The situation was similar in the relations between Kaliningrad and Lithuania. For example, 2.5 to 5 thousand persons crossed the border daily at Gronowo-Mamonowo before Poland's accession to the Schengen Area. In 2008, this number dropped to a mere 1.5 to 2 thousand. The introduction of visas between Poland and Russia hindered and restricted the local border trade, which had for years been the only measure mitigating social and economic problems of the cross-border regions. Nevertheless, border traffic between Poland and Kaliningrad grew regularly exceeding four million in 2012 (Table 1).

In October 2007, talks were held by the EU Commissioner for external relations and the Council of the Baltic Sea States with the Russian counterpart during which the EU confirmed its readiness to introduce a special procedure for Polish and Lithuanian local border traffic for inhabitants residing within a 30 kilometre zone. Such guidelines for border zones meant that a narrow strip of land in Kaliningrad itself would not be covered by the agreement. The Russian authorities therefore made efforts for the small border traffic regulations to cover up to $50 \mathrm{~km}$ inland from the Polish and Lithuanian border.

In 2009, an idea was voiced for Poland, Lithuania and Russia to apply to the European Commission with an initiative for the small border zone to cover the entire Kaliningrad Oblast. It was assumed that an extended zone would be established in the Polish and Lithuanian zone 
Table 1. Individual traffic on the Polish border with the Kaliningrad Oblast of the Russian Federation in the years 2007-2012

\begin{tabular}{|c|c|r|r|r|r|c|c|}
\hline \multirow{2}{*}{ Years } & \multicolumn{9}{|c|}{ Border crossing in thous. persons } \\
\cline { 2 - 8 } & \multirow{2}{*}{ Total } & \multicolumn{4}{|c|}{ Poles } & \multicolumn{3}{c|}{ Foreigners } \\
\cline { 2 - 8 } & & total & from Poland & to Poland & total & from Poland & to Poland \\
\hline 2007 & $2,910.5$ & $1,479.9$ & 727.0 & 752.9 & $1,430.6$ & 718.0 & 712.5 \\
\hline 2008 & $1,915.6$ & $1,128.7$ & 556.3 & 572.5 & 786.9 & 401.1 & 385.8 \\
\hline 2009 & $1,276.3$ & 572.2 & 283.3 & 289.0 & 704.1 & 364.7 & 339.4 \\
\hline 2010 & $1,451.5$ & 535.5 & 267.9 & 267.7 & 915.9 & 484.2 & 431.7 \\
\hline 2011 & $2,373.5$ & $1,020.2$ & 495.8 & 524.4 & $1,353.3$ & 684.8 & 668.5 \\
\hline 2012 & $4,073.1$ & $2,052.2$ & $1,017.6$ & $1,034.6$ & $2,020.9$ & $1,005.6$ & $1,015.4$ \\
\hline
\end{tabular}

Source: www.strazgraniczna.pl

on the basis of reciprocity. However, Lithuania withdrew from this initiative. because of an earlier refusal of Russia to sign an agreed understanding on non-visa traffic in a $30-\mathrm{km}$ border zone. Lithuania's doubts also resulted from a growing concern that with the entire Oblast covered by small border traffic, too much of the country's area would be exposed to it.

Poland and Russia, supported by Germany, applied to the EU to cover the entire Oblast with small border traffic in April 2010. A year later the project was accepted by Brussels. According to the European Commission, the proposed solution would be an exception at the European scale. It is a necessity because of the unique location of the Kaliningrad Oblast. The recognition of the entire Oblast as a border zone prevents an artificial division of the region and facilitates economic and cultural exchange. The Polish-Russian proposal was approved by the European Council and Parliament. On 14 December 2011 the Polish and Russian Ministers of Foreign Affairs signed a bilateral agreement in Moscow, which was ratified in Warsaw on 4 May and in Moscow on 16 June 2012 and came into force on 27 July 2012.

The agreement on small border traffic covered the entire Kaliningrad Oblast and, on the Polish side, Pomerania with the cities of Sopot, Gdańsk and Gdynia and Puck, Gdańsk, Nowy Dwór and Malbork poviats; as well as Warmia-Mazuria voivodship with the cities of Elbląg and Olsztyn as well as Elbląg, Braniewo, Lidzbark, Bartoszyce, Olsztyn, Kętrzyn, Mrągowo, Węgorzewo, Giżycko, Gołdap and Olecko poviats (Fig. 1).

Residents of the Kaliningrad Oblast inhabiting it for at least three years are entitled to a special pass for a period of two to five years for a fee of 20 euros. They can stay on the territory of Poland covered by the agreement for 30 days, however not more than 90 days in six months. Oblast residents are issued passes on applying to the Consulate of the Republic of Poland in Kaliningrad, whereas Poles intending to visit Kaliningrad can obtain passes from the Embassy of the Russian Federation in Warsaw and the General Consulate of the Russian Federation in Gdańsk. The passes do not entitle their holders to undertake employment or start business in the neighbouring country.

Small border traffic involves only land border crossings (by road and railway): Gronowo-Mamonowo, Bezledy-Bagrationovsk, Gołdap-Gusev and the road border crossing GrzechotkiMamonowo II starting December 2010. What is missing, particularly in view of developing tourism, is the option of using marine border crossings.

The developing relations between Kaliningrad residents and their EU neighbours even before the small border traffic agreement indicated that the new options opened since the end of July 2012 would contribute to more dynamic development of these relations. And that was the case. By the end of the first quarter of 2013, the number of Poles crossing the border increased, and starting from the second through third quarters of 2013 the number of foreigners, mainly Russian nationals coming to Poland, showed dynamic growth (Fig. 2).

The group of foreigners, mainly Russians from Kaliningrad crossing the border under the small border traffic agreement, keeps growing (Figs 3 and 4).

The visits of Kaliningrad residents, apart from commercially oriented ones, also include recreation, tourism, medical care related visits, etc. 


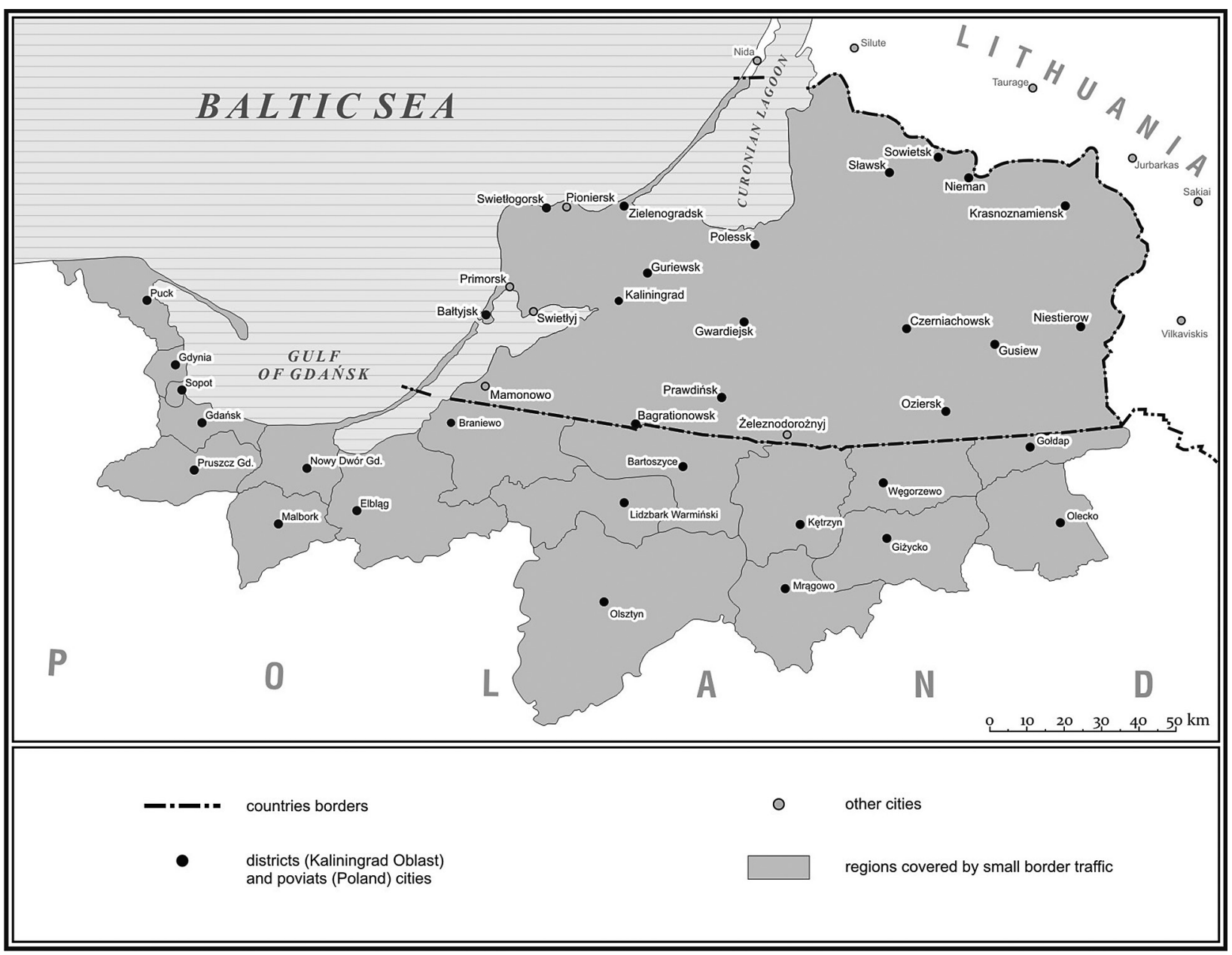

Fig. 1. Kaliningrad Oblast and border regions in Poland covered by the agreement on small border traffic starting on 27 July 2012

Source: own study based on: www.strazgraniczna.pl

Kaliningrad residents looking for recreation and ways of spending leisure time come to participate in big sporting and cultural events, e.g. music concerts held at the new Baltic Arena stadium or the Ergo Arena Hall in Gdańsk. In Tri-City they often visit Gdańsk, the Oliwa zoological gardens, or the Sopot and Gdynia beaches.

The local self governments of poviats covered by small border traffic noted a clear upturn in the economies and trade of their regions. The inhabitants of both countries enjoy lower prices of foodstuffs, clothing, electronic appliances, or furniture and building materials. Poles buy gasoline and tobacco products at half a price.

The growing interest in shopping in Poland following the introduction of the new regulations on small border traffic is illustrated in the comparative studies conducted by the Regional Development Geography Department of the
Gdańsk University in the Matarnia shopping mall in Gdańsk on the turn of May and June in 2010 and 2013 (Table 2). The Mall comprises 57 shops and salons providing various services, including

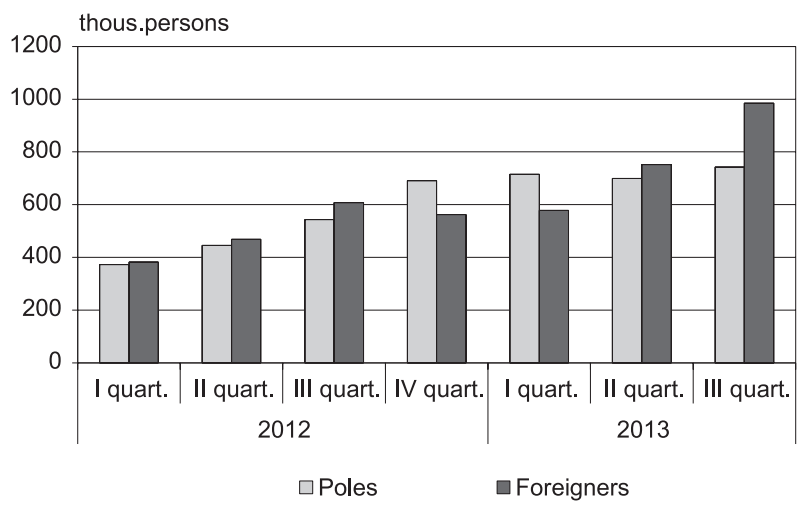

Fig. 2. Border traffic of Poles and foreigners on the border of Poland and the Kaliningrad Oblast of the Russian Federation in 2012 and the first three quarters of 2013 Source: own study based on: www.strazgraniczna.pl 


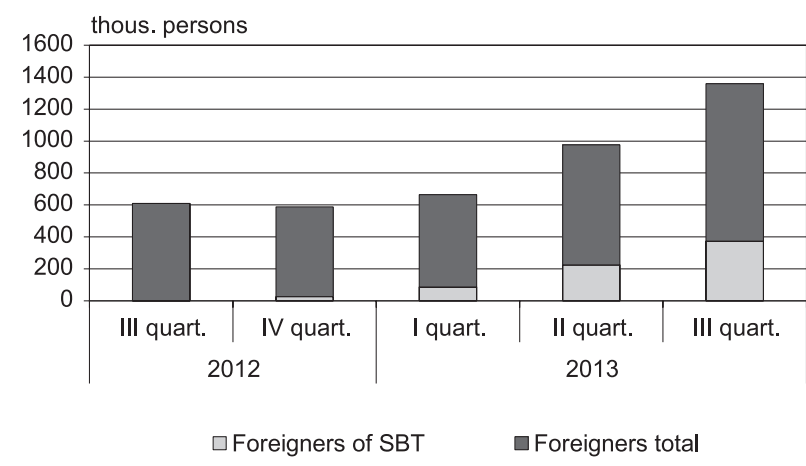

Fig. 3. Number of foreign individuals crossing the Polish-Kaliningrad border, including those with documents issued under the small border traffic (SBT) agreement Source: own study based on www.strazgraniczna.pl

IKEA, a store with household goods very popular with Russians. Observations made during two work days and two off-work days in analogous periods in 2010 and 2013 showed a 12-fold growth in the number of Kaliningrad residents shopping in the biggest shopping mall in the Tri-City after introducing visa-free traffic in the border region.

The holiday season shows an even higher rate. A record number of shoppers turned up between Christmas and the beginning of 2014, a period which means over a week off work for Russians. In that period over 30\% more individuals than usual crossed the border with Kaliningrad.

The volume of Russian shopping in Poland can be seen by the number of VAT-free invoices issued - a type of invoice required to recover tax under Tax Free regulations. According to the data of the Customs Office in Olsztyn, Kaliningrad residents presented approximately 40 thousand invoices for a total sum of 55 million zlotys. In 2013 there were over 115 thousand such invoices noted. They documented purchases worth a total of PLN 94.8 million. Since the return of VAT invoices qualifying for VAT reimbursement is not issued by hotels, catering facilities and some discount shops, the actual expenditure of Russians in Poland is several times higher.

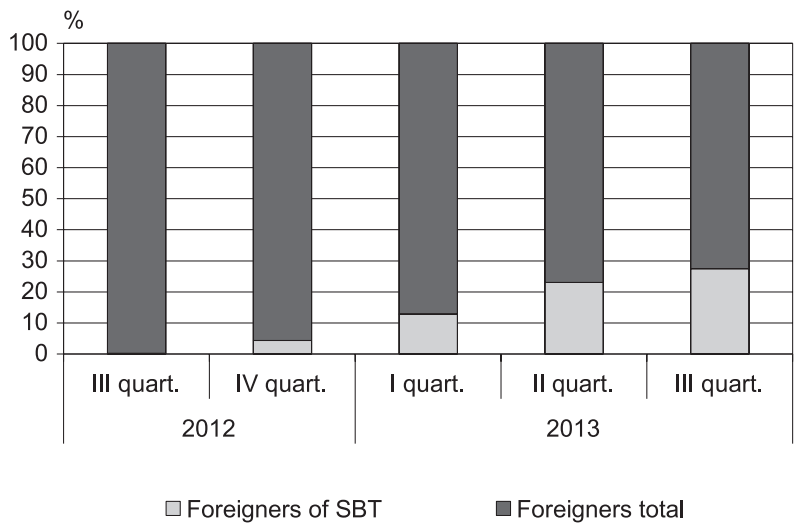

Fig. 4. Structure of individual traffic of foreigners on the Polish-Kaliningrad border, including those with documents issued under the small border traffic (SBT) agreement Source: own study based on www.strazgraniczna.pl

Tourist trips of Poles to the Kaliningrad Oblast develop much slower. This region features exceptionally favourable climate conditions as well as a good natural and a cultural environment for developing tourism. The Kaliningrad coast is among the few coastal regions of Russia well qualified for summer recreation. Natural conditions and the right infrastructure place tourism and recreation among priorities in the Oblast's economic development. As early as in 1996 outstanding Kaliningrad experts G. Fedorov and V. Korneyevets classified the key areas of its development taking into account international, national and regional interests (Table 3). The table shows not only diversified interests but also discrepancies and conflicts of interest, particularly in terms of the Russian Federation and the Kaliningrad Exclave. It also points to the eminent role of cross-border cooperation as well as tourism, recreation, and environmental protection.

The maritime climate, sandy beaches on the Vistula Spit and Curonian Spit and the healing mineral waters and therapeutic peat have allowed the development of sanatorium and holiday resorts in the coastal zone. The key centres for therapy and leisure are health resorts in Zele-

Table 2. Russians in the Matarnia shopping mall in Gdańsk in the years 2010 and 2013

\begin{tabular}{|c|c|c|c|c|}
\hline \multicolumn{5}{|c|}{ Russians in the Matarnia shopping mall (persons) } \\
\hline Thursday & Friday & Saturday & Sunday & total \\
\hline 26 May 2010 & 27 May 2010 & 28 May 2010 & 29 May 2010 & 26-29 May 2010 \\
\hline 23 & 27 & 76 & 68 & 194 \\
\hline 5 June 2013 & 6 June 2013 & 7 June 2013 & 8 June 2013 & 5-8 June 2013 \\
\hline 328 & 377 & 950 & 607 & 2,262 \\
\hline
\end{tabular}

Source: own field research 
Table 3. Regional development priorities of the Kaliningrad Oblast

\begin{tabular}{|c|c|c|c|c|c|}
\hline Key development sectors & Inter-regional & National & Regional & Local & Sectoral \\
\hline \multicolumn{6}{|l|}{$\begin{array}{l}\text { Transport network } \\
\text { including: }\end{array}$} \\
\hline a) roads & $* * *$ & * & $* * *$ & ** & $* * *$ \\
\hline b) railways & $* *$ & * & $* *$ & * & $* *$ \\
\hline c) ports & * & $* * *$ & $* * *$ & $* *$ & ** \\
\hline d) airports & * & * & $* *$ & * & $*$ \\
\hline Tourism and recreation & $* *$ & * & $* * *$ & $* *$ & * \\
\hline Energy & * & ** & ** & * & * \\
\hline Agriculture & * & * & $* * *$ & $* * *$ & $* * *$ \\
\hline Fishing & * & * & $* * *$ & $* * *$ & $* * *$ \\
\hline $\begin{array}{l}\text { Celluloid and paper in- } \\
\text { dustry }\end{array}$ & * & * & $* *$ & ** & ** \\
\hline $\begin{array}{l}\text { Social and economic situ- } \\
\text { ation }\end{array}$ & ** & ** & $* * *$ & $* * *$ & $* *$ \\
\hline $\begin{array}{l}\text { Sustainable development } \\
\text { of towns }\end{array}$ & ** & ** & $* *$ & $* * *$ & * \\
\hline Agricultural development & ** & * & $* *$ & $* * *$ & * \\
\hline $\begin{array}{l}\text { Military industry conver- } \\
\text { sion }\end{array}$ & $* *$ & - & * & - & - \\
\hline Demilitarisation & $* * *$ & - & ** & ** & * \\
\hline Environmental protection & $* * *$ & * & $* *$ & $* *$ & - \\
\hline Special economic zone & $* *$ & - & $* * *$ & $* * *$ & ** \\
\hline Cross-border cooperation & $* *$ & - & $* * *$ & $* *$ & $*$ \\
\hline Total & 31 & 18 & 41 & 35 & 26 \\
\hline
\end{tabular}

*** top priority, ** high priority, * low priority, - no priority

Source: Fedorov, Korneyevets (1996: 47)

nogradsk, Svetlogorsk and Pionersk with numerous sanatoriums, hotels, holiday resorts, guest houses and tourist centres. The area is covered by a therapeutic zone development plan.

Since the beginning of the 1990s, the tourist structure in the Kaliningrad Oblast has been subject to change. The tourist infrastructure is also undergoing change. In many hotels and resorts the quality of services provided has improved to equal top European standards.

The tourist business has also evolved. Over 100 tourist agencies organise trips in the Oblast and to other regions of Russia and abroad. The inclusion of the Kaliningrad Oblast ino Baltic Europe tourist routes and the development of business tourism has stimulated the growth of high-standard tourist infrastructure, as shown by the intense growth in the number of hotels and holiday resorts. The years 2000-2005 saw the launching of 24 hotels and holiday resorts for 700 guests.

Accommodation facilities have undergone a substantial upgrading. Hotels, both old and new, have experienced a 'face lift' to satisfy contemporary standards. Smaller guest houses have appeared. These changes mostly involve Kaliningrad and health resorts in Svetlogorsk and Zelenogradsk as well as several border region locations such as Sovietsk and Bagrationovsk.

In recent years the tourism sector in the Oblast has been experiencing dynamic development. In the years 1997-2008, the number of tourists visit-

Table 4. Tourists in the Kaliningrad Oblast in the years 2004-2010

\begin{tabular}{|l|r|r|r|r|r|r|r|}
\hline Years & 2004 & 2005 & 2006 & 2007 & 2008 & 2009 & 2010 \\
\hline Russian tourists & 240 & 257 & 284 & 308 & 425 & 312 & 367 \\
\hline Foreign tourists & 71 & 76 & 82 & 88 & 95 & 78 & 53 \\
\hline Total & 311 & 333 & 366 & 396 & 520 & 390 & 420 \\
\hline
\end{tabular}

Source: own study based on data of the Kaliningrad Oblast government authorities 
ing the region increased from 165 to 520 thousand persons, three out of four of whom were Russians. In the next two years the numbers dropped, showing 420 thousand in 2010 (Table 4).

In the record year of 2008, 425 thousand guests, i.e. 77\%, were Russian. In 2010 the number of Russians read 367 thousand - over $85 \%$ of all guests. Half of them were tourists from the Oblast, with the other half representing tourists from other regions of Russia.

International tourism started developing after 1990 when the Oblast opened to foreigners. 60-70 thousand guests from abroad arrive annually to the Oblast. The biggest number of foreign tourists was noted in 2008 - 95 thousand. The next years showed a considerable fall in the number of foreigners visiting the area, with a drop to 53 thousand in 2010. Half of the foreign tourists came from Germany, $18 \%$ from Poland, $12 \%$ from the Baltic countries. The remaining tourists came from Scandinavia, Belarus and other countries. Due to the typical seasonal nature of the Baltic Sea, the hotels are $100 \%$ full in summertime (from May to September), while the occupancy rate out of season is $30-40 \%$.

A new form of spending leisure time in the Oblast is agro-tourism. Approximately 70 agro-tourist homesteads have been established, mainly in the Zelenogradski, Polesski, Slavski and Nesterovski regions. They host both Russians and foreign guests. Businesses benefit from experience gained in Poland. Projects for the development of agro-tourism have appeared in rural habitats on the northern coast of the Sambia Penninsula. These projects involve such locations as Grachevka, Jantarnyj, Russkoye, Pereslavsk, Romanovsk and Melnikovsk.

Tourism development plans assume further growth of guest rooms in the coastal therapeutic zone, in Kaliningrad, the Curonian and Vistula Spits, on the southern coast of the Vistula Spit, on the southern and eastern coast of the Curonian Spit, in the Vishtinetzki region, and in the valleys of the Lyna, Pregolya, Šešupe and Neman rivers.

The Khrabrovo airport and the developed road network favour the development of tourism facilitating access to the coastal zone. Ultimately, this part of the Oblast is to be ready to host 34 thousand guests all year round and 90 thousand high-season guests. Together with tourists com- ing for a short stay, during the summer season the area can host over 200 thousand guests at the same time. The spa locations - Zelenogradsk, Svetlogorsk and Pionersk - will continue to grow as major tourist, holiday and treatment centres.

The adopted directions of further development foresee therapeutic tourism businesses on the coast welcoming domestic and foreign guests. Other trends involve recreation and spa services as well as angling, spending leisure time on lakes and in forest areas, sentimental and historical journeys, cycling tourism, horse riding, and golf. Ecological tourism, eco-tourism and agro-tourism as well as conference and business tourism show a great future potential.

Though the development of cross-border cooperation, including small border traffic, has basically failed to draw numerous tourists from Poland to the most attractive tourist locations in the Kaliningrad Oblast, it provides such an opportunity. This region, like Russia in its entirety, is quite expensive for the average Pole. However, as scientists from Kaliningrad anticipated, with the easing of the visa system and the development of transport and tourist infrastructure, the role of tourism shows an upward tendency. Its growing role may prove to be a significant factor contributing to further dynamic progress in cross-border cooperation.

\section{References}

Fedorov G., Korneyevets V., 1996. Multilevel interests for the development of the Kaliningrad Region as an enclave territory of Russia. In: Vision and Strategies around the Baltic Sea 2010, IÖR Schriften 17, Dresden: 45-47.

Fedorov G., Korneyevets V., Zwerev Y., 2011. Kaliningrad Oblast of Russia in the transborder region of south-eastern Baltic. Coastal Regions 19. University of Gdańsk, GdańskPelplin.

Fiedorow G., Korniejewiec W., Zwieriew J., 2007. Obwód Kaliningradzki (Kaliningrad Oblast). In: Palmowski T. (ed.), Pogranicze polsko-rosyjskie. Problemy wspótpracy transgranicznej z Obwodem Kaliningradzkim. Wydawnictwo Bernardinum, Gdynia-Pelplin: 142-211.

Kropinova E., Bruce D., 2009. A new Russian window to the West: the Province of Kaliningrad. In: Holloway J.Ch. (ed.), The business of tourism. FT Prentice Hall, Financial Times, London-New York-Boston: 707-731.

Palmowski T., 2008. Problemy współpracy transgranicznej Trójmiasta z Obwodem Kaliningradzkim (Problems in the transborder cooperation of Tri-City with the Kaliningrad Oblast). In: Ignasiak-Szulc A., Kosiedowski W. (eds), Problemy wspótpracy gospodarczej w Regionie Battyc- 
kim w kontekście integracji europejskiej. Towarzystwo Naukowe Organizacji i Kierowania „Dom Organizatora”, Toruń: 141-150.

Palmowski T., 2010. Problems of cross-border cooperation between Poland and the Kaliningrad Oblast of the Russian Federation. Quaestiones Geographicae 29(4): 75-82.

Palmowski T., Anisiewicz R., 2003. Development of new form of co-operation between the Tri-City and Kalinin- grad district. In: Palmowski T., Fedorov G., Korneyevets V. (eds.), Economic, geopolitical and social problems of co-operation between Kaliningrad and Poland, Coastal Regions 6.

University of Gdańsk, Gdynia-Pelplin: 100-114. www.olsztyn.ic.gov.pl ( accessed 10 January 2014) www.strazgraniczna.pl (accessed 8 January 2014) 